International Journal of Linguistics, Literature and Translation (IJLLT)

ISSN: 2617-0299 (Online); ISSN: 2708-0099 (Print)

DOI: 10.32996/ijllt

Website: https://al-kindipublisher.com/index.php/ijllt

\title{
Translation Technique of Women Anger Speech Act in Television Series 13 Reasons Why \\ Season 1
}

Hayati Elmarhamah Syarif ${ }^{1 *} \&$ M.R. Nababan ${ }^{2}$ Riyadi Santosa ${ }^{3}$

${ }^{1}$ Postgraduate Student, Linguistic Program, Sebelas Maret University, Surakarta, Indonesia

${ }^{2}$ Professor, Linguistic Program, Sebelas Maret University, Surakarta, Indonesia

${ }^{3}$ Professor, Linguistic Program, Sebelas Maret University, Surakarta, Indonesia

Corresponding Author: Hayati Elmarhamah Syarif., E-mail: hayatielmarhamah@gmail.com

ARTICLE INFO

Received: September 12, 2020

Accepted: October 22, 2020

Volume: 3

Issue: 10

DOI: $10.32996 /$ ijllt.2020.3.10.19

\section{KEYWORDS}

Anger Speech Act, Translation Technique, Television Series, English- Indonesia
The study aimed to analyze the translation technique used in women's anger speech acts in a television series entitled 13 Reasons Why Season 1. This study was a descriptive qualitative research and an embedded case study. Analysis document and Focus Group Discussion (FGD) were used to collect the data. The result shows the behaviour patterns of the translator using various translation techniques in all types of speech acts including direct verbal or cognitive sign, thinly veiled verbal sign, and indirect verbal sign. The most frequently used techniques in direct verbal or cognitive signs are establish equivalent and followed by variation and explicitation, while establish equivalent, variation, and pure borrowing are frequently used in thinly veiled verbal signs and indirect verbal signs. In addition, compensation technique is only used in direct verbal or cognitive signs and indirect verbal signs while paraphrase is used in translating anger speech acts in terms of direct verbal or cognitive signs and thinly veiled verbal signs. Meanwhile, other techniques such as generalization, linguistic amplification, linguistic compression, and adaptation are the least frequent techniques used in direct verbal or cognitive signs and thinly veiled verbal signs.

\section{Introduction}

A translation is a crucial part of people in this modern era. It connects people to get information from all over the world. The translation not only covers science and technology but also cultures. Since it has a crucial role in delivering a particular message, a translator must careful in translating the text to attain a good quality of translation.

A good quality of translation could be acquired if the translator maintains the accuracy, acceptability, and readability of the translation (Nababan, Nuraini \& Sumardiano, 2012). To maintain these three things, not only translators should understand well both of languages and cultures in source and target language, but also translators should know appropriate techniques in translating words, phrases, or sentences.

Translation techniques play an important role in creating a good translation. The translator's mistakes in choosing a certain translation technique affect the quality of the translation. It leads to inaccurate messages, and readers probably misinterpret the translation. Moreover, it could confuse them to get the point of the text.

One of the mistakes often be made by a translator is in translating anger speech acts. The anger speech act is a part of the expressive speech acts in the illocutionary acts of pragmatics used to express the feeling of a speaker. Anger is one of the crucial human expression. It is an emotion that arises because of frustration or a hurtful feeling. People show anger by

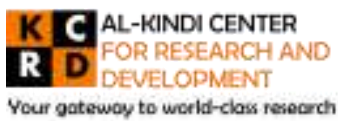

Your gatewoy to world-class resecrch
Published by Al-KindiCenter for Research and Development. Copyright (c) the author(s). This is an open access article under CC BY license (https://creativecommons.org/licenses/by/4.0/) 
attacking or hurting someone. It is shown by the verbal attack in terms of anger speech acts, such as blaming, mocking, sarcasm, etc. (Tucker-Ladd, 1998).

However, some studies found that women and men have their way of using languages including expressing anger. For instance, Spender in Meng (2019) stated that language patterns used by women and men are manifestations of the Patriarchy system. Moreover, Mehl and Pennebaker (2003) found that men use speech acts representing anger three times more than women and swear words four times more than women.

This led to the question of whether these differences of using anger speech act by women or men in translation affect the character of the language pattern itself as well as the quality of the translations. If a translator using wrong or inappropriate techniques in translation, there would be a higher chance that there will be a distortion of meaning. Moreover, it leads to translation shifts.

As the consequence, this study was conducted to find out the translation techniques of women's anger speech acts. In this study, a television web series, 13 Reasons Why Season 1 is used as the research location. It was adapted from the Novel 13 Reasons Why By Jay Asher. The television series has a storyline showing teenage life full of anger, revenge, and bullying. Accordingly, this television series is considered as a good location to exhibit the use of anger speech acts by women.

There are some studies related to this study, conducted by Ardi (2011), Hafisha (2018), and Wahana (2019). Ardi analyzed the expression of anger on women and men in a Film entitled Butterfly Effect. The study aimed to find out the classification and the type of anger expression using Mack Li Mause and Arthur T Jersild's theory. Besides, she also analyzed the response of anger expression using Timothy Jay's theory. The result shows that men use indirect anger fewer than women. In fact, women do not use direct anger at all. The form of anger expression mostly is declarative verbal anger. Meanwhile, the response of anger mostly in an expressive way rather than a suppressive way. Other study was conducted by Hafisha. She analyzed the type of anger speech act in Novel Twilight by Stephany Meyer using Yule's theory. Meanwhile, Wahana analyzed the type of anger speech act using Searle's theory and translation ideology using Newmark's theory in Webtoon "Flawless". Both of these studies also analyzed translation techniques and translation quality on anger speech act using Molina Albir and Nababan et al's theories. The result of Hafisha's study showed that the actor uses 4 types of the speech act in expressing anger, Representatives, Directives, Expressive, and Comissive. Meanwhile, the result of Wahana's study showed that most anger speech act expressions frequently used are, expressive, assertive, and followed by directive. In addition, both Hafisha's and Wahana's show that most of the data are accurate, acceptable, and high readability. Ardi's study has already focused on gender, women, and men, but the study does not relate to translation. Meanwhile, even though Hafisha's and Wahana's studies are already related to anger expression, but there is still no translation analysis that only focuses on women's anger expression.

Based on the previous studies, the researcher is interested to analyze women's anger speech acts translation on the Television series, 13 Reasons Why Season 1. The study aims to find out translation techniques of anger speech act by women in the Television series, 13 Reasons Why Season 1.

\section{Literature Review}

\subsection{Translation}

There are many definitions of translation. According to Cadford (1965) Translation is a substitution of text from a source language into a target language equivalently. Nida and Taber (1982) add that there are two important things in translating a text: delivering the message and translating the text by using the most similar style of the source text. Newmark (1988) also stated that translating is the capability in transferring a written text from a source language into a target language as a communication, as a tool in sharing the culture and language learning, and also as an entertaining thing. To deliver the message, the translator needs to know both the language and the culture of the source language and target languages so that the text could be translated equivalently.

There are some stages that should be done in translating the text. Suryawinata in Nababan (2008) explained the process during translating a text. The first step is analyzing the source text. Then the translator translates the text into his mind. The last stage is the reconstruction. In this process, the translator converts the message into the stylistic form of the target language.

\subsection{Translation Technique}

A translation technique is a procedure used to analyze and classify a translation (Molina and Albir, 2002). Molina and Albir explained that there are 18 translation techniques as followed: 
Adaptation To find cultural equivalence from the source language into the target language. This technique occurs when the translator does not find the cultural element in the target language.

For example: "as white as snow" is translated into "seputih kapas"

Amplification To give detailed information in the target text that is not provided in the source text. This technique corresponds to SCFA's explicitation, Delisle's addition, Margots' legitimate and illegitimate paraphrase, Newmark's explicative paraphrase, and Delisle's periphrasis and paraphrase.

For example: "Look at them" is translated into "Lihatlah kucing-kucing itu"

Borrowing The technique that is done by borrowing the source language in the target text, a phrase or a word, in form of pure borrowing or neutralization.

For example: "Asparagus" is translated into "Asparagus"

Calque The translation technique that is done by translating the word literally, whether it is structurally, or lexically.

For example: "Assistance Residencies" is translated into "Asisten Keresidenan"

Compensation To introduce stylistic elements from the source text in the target text.

For example: "such an asshole" is translated into "Brengsek"

Description To replace the term in source text with a description of form or function in the target text.

For example: "Black Pudding" is translated into "Sosis tradisional yang terbuat dari darah babi kering dan lemak"

Discursive Creation The technique used to get the reader's interest or to make temporary equivalence translation that probably be out of the context.

For example: "Korean Beckons" is translated into "Selayang Pandang Korea"

Establish Equivalent Translation techniques that use term or expression that already common in the target language. The term or expression is used in daily life in a particular field or situation.

For example: "Discussed" is translated into "membahas"

Generalization To change a word, phrase, or a sentence in the source text into a word, a phrase, or a sentence that is more general or neutral in the target language.

For example: "The landlord" is translated into "pemiliknya"

Linguistic Amplification To add a linguistic element in the target language to specify or to describe more about a word, a phrase, or a sentence. This technique is also often used in consecutive interpreting or dubbing.

For example: "Pardon me" is translated into "Dapatkah anda mengulang ucapan anda"

Linguistic Compression This technique is the opposite of Linguistic Amplification. It is done by synthesizing the linguistic element in the target language. It usually uses in simultaneous interpreting and subtitling.

For example: "I want you to know that" is translated into "Ketahuilah"

Literal Translation Translating word by word based on the dictionary from the source text into the target text. This technique is also referred to as a word for word translation.

For example: Really? is translated into "Sangat?"

Modulation To change the perspective in terms of focus or cognitive aspect lexically or structurally from the source text into the target text.

For example: "Nobody doesn't like it" is translated into "Semua orang menyukainya"

Particularisation This technique is used when the translator wants to specify a word, a phrase, or a sentence from the source text into the target text.

For example: "Rain" is translated into "Gerimis"

Reduction To omit or reduce linguistic elements in the target text without changing the intended meaning.

For example: "Where the hell is Justin" is translated into "Dimana Justin?" ("the hell" is omitted)

Substitution To change linguistic element into paralinguistic in form of gesture or intonation or vice versa.

For example: "I don't agree with you" is translated into a gesture of shaking his head.

Transposition To change the grammatical system from the source language into the target language. It could be in for of word into a phrase or vice versa.

For example: "How could you. . ." is translated into "teganya Kau. . ."

Variation To change the linguistic element or paralinguistic elements in the source language like changing the style of the text, social dialect, or geographical dialect. This technique is often used in translating drama text.

For example: "You" is translated into "Kau"

\subsection{Anger Speech Act}

The speech act is a part of the pragmatic study. Pragmatic is a study about the relation between language and context (Levinson, 1983). It is a study about the meaning of utterances conveyed by a speaker to a listener or listeners. To know the whole meaning 
of an utterance the listener needs to connect the utterance with the context and the situation so that the intended meaning will be understood. One of the pragmatic aspects is a speech act that is divided into 3 by Yule (1996): Locutionary Act, Perlocutionary Act, Illocutionary act. Searle (1969) divides illocutionary act further into 5: comissive, directive, assertive, declaration, and expressive. Expressive is one of the illocutionary act functioning as a speech act to express the speaker's feeling such as apologizing, complimenting, regretting, showing happiness, showing anger, etc.

A speech act that shows anger or called anger speech act is a speech act containing the speaker's anger. It could be in form of mocking, sarcasm, blaming, etc. Madow in Tucker-Ladd (1998) explains the type of anger speech act as follow:

Direct verbal or cognitive signs In this type, the speech act is said directly without thinking of the listener's feelings. The speaker said the anger clearly. This type of speech act is divided as follows:

- Open hatred and insult: "You're so fucking stupid"

- Contempt and disgust: "You are a fat pig"

- Critical: "Get your dirty hand off my book"

- Suspicious: "You cheated"

- Blaming: "You are the damn thief"

- Demeaned: "She does not deserve the respect"

- Revengeful: "I'll kill you dead"

- Name-calling: "You are such a bitch"

- Less intense but clear: "You're such a pain"

Thinly Veiled Verbal Signs Thinly anger could be seen in the speech act. The speaker does not express the anger bluntly in the speech act, but by saying a thin expression of anger.

For example: "I am not mad, but just annoyed by your behavior".

Indirect verbal signs In this type of speech act anger is conveyed indirectly. The speaker intentionally does not express the anger by saying a harsh word but showing the sign that she is angry. For example: "I don't wanna talk to you", "I am disappointed in you"

\section{Methodology}

This study was a descriptive and qualitative approach. The qualitative approach focuses on observation, interviews, or document review (Moelong, 2010), while the descriptive research focuses not only on collecting the data but also on analyzing and interpreting the data (Surachmen in Abdurrahman, 1999). This study was also an embedded study because the researcher has already chosen the topic before the study was conducted (Sutopo, 2006). According to Santosa (2017), a research location includes geographic, demographic, and media. In this study, the location is in form of media, a television series. The focus of this study was to analyze translation techniques used in translating anger speech acts by women in the subtitle of the television series, 13 Reasons Why Season 1. The source data was taken from the television series, 13 Reasons Why Season 1, and the subtitle by Artha Regina taken from subscenne.com. The data were collected by analyzing the document and Focus Group Discussion (FGD).

\section{Results and Discussion}

The result shows that there are 117 anger speech acts used by women in television series, 13 Reasons Why Season 1. The translator used Madow's theory in differentiating the type of women's anger speech acts. Meanwhile, the Molina and Albir theory was used in analyzing translation techniques in television series, 13 Reasons Why Season 1. The types of anger speech act and translation techniques are provided in the componential table adapted from Santosa (2017) as follow:

Table 1. Types of Anger Speech Acts and their Translation Techniques

\begin{tabular}{|c|c|c|c|c|c|c|c|c|c|c|c|c|c|c|c|c|c|}
\hline \multirow{2}{*}{\multicolumn{2}{|c|}{ Types of Anger Speech Acts }} & \multicolumn{16}{|c|}{ Translation Techniques } \\
\hline & & $\mathrm{EE}$ & $\mathrm{Va}$ & PB & Ex & Mo & DC & Im & $\operatorname{Re}$ & $\mathrm{Pa}$ & Li & $\mathrm{Tr}$ & $\mathrm{Ge}$ & LA & LC & Ad & C \\
\hline \multirow{5}{*}{$\begin{array}{l}\text { Direct } \\
\text { Verbal or } \\
\text { Cognitive } \\
\text { Sign (58) }\end{array}$} & Critical (26 data) & 130 & 38 & 8 & 19 & 13 & 4 & 5 & 4 & - & 2 & 1 & 1 & 1 & - & - & 2 \\
\hline & $\begin{array}{l}\text { Less Intense but } \\
\text { Clear ( } 15 \text { data) }\end{array}$ & 25 & 3 & 4 & 4 & 1 & - & 3 & 4 & 1 & - & - & - & - & - & 1 & - \\
\hline & Blaming (6 data) & 27 & 7 & 1 & 1 & 1 & - & 2 & - & - & - & 1 & - & - & - & - & 1 \\
\hline & $\begin{array}{l}\text { Name-calling (5 } \\
\text { data) }\end{array}$ & 8 & 4 & - & 2 & 1 & - & - & - & - & - & - & - & - & - & - & 1 \\
\hline & $\begin{array}{l}\text { Suspicious (4 } \\
\text { data) }\end{array}$ & 8 & 3 & - & 3 & 1 & - & - & - & 1 & 1 & - & - & - & - & - & - \\
\hline
\end{tabular}




\begin{tabular}{|c|c|c|c|c|c|c|c|c|c|c|c|c|c|c|c|c|}
\hline $\begin{array}{l}\text { Open Hatred and } \\
\text { Insult ( } 2 \text { data) }\end{array}$ & 10 & 3 & - & - & 2 & - & - & - & - & - & - & - & - & 1 & - & - \\
\hline $\bar{\Sigma}$ & 208 & 58 & 13 & 29 & 19 & 4 & 10 & 8 & 2 & 3 & 2 & 1 & 1 & 1 & 1 & 4 \\
\hline $\begin{array}{l}\text { Thinly Veiled Verbal Sign ( } 36 \\
\text { data) }\end{array}$ & 131 & 14 & 13 & 11 & 9 & 6 & 5 & 3 & 2 & 1 & 1 & 1 & 1 & 1 & 1 & - \\
\hline Indirect Verbal Sign (23 data) & 72 & 21 & 7 & 4 & 4 & 3 & 1 & 2 & - & 1 & 1 & - & - & - & - & 1 \\
\hline$\Sigma$ & 411 & 93 & 33 & 44 & 32 & 13 & 16 & 13 & 4 & 5 & 4 & 2 & 2 & 2 & 2 & 5 \\
\hline
\end{tabular}

Table 1 explanations:

$\mathrm{EE}=$ Established Equivalent, $\mathrm{Va}=$ Variation, $\mathrm{PB}=$ Pure Borrowing, $\mathrm{Ex}=$ Explicitation, $\mathrm{Mo}=$ Modulation, $\mathrm{DC}=$ Discursive Creation, $\mathrm{Im}=$ Implicitation, $\mathrm{Re}=$ Reduction, $\mathrm{Pa}=\quad$ Paraphrase $, \mathrm{L}=\mathrm{L}=\mathrm{Literal}, \mathrm{Tr}=\mathrm{Transposition}, \mathrm{Ge}=$ Generalisation, $\mathrm{LA}=\mathrm{Linguistic}$ Amplification, $\mathrm{LC}=$ Linguistic Compression, $\mathrm{Ad}=$ Adaptation, $\mathrm{C}=$ Compensation

Table 1 indicates the trend or behavior pattern of the translator in transferring women's anger speech acts in television series 13 Reasons Why Season 1 from the source text into the target text, as the following.

First, the translator tends to use different translation techniques in translating woman anger speech act in all types of anger speech acts: direct verbal or cognitive sign, thinly veiled verbal sign, and indirect verbal sign.

Second, Direct verbal or cognitive signs are frequently translated with establish equivalent followed by variation and explicitation while thinly veiled verbal signs and indirect verbal signs are frequently translated with establish equivalent, variation, and pure borrowing. Since these four techniques transfer the meaning equivalently without any distortion meaning, the translator uses these techniques a lot in translating the anger speech acts. The followings are the samples of each technique. Establish Equivalent

Establish equivalent was the dominant translation technique used in translating anger speech act in all types of anger speech acts because it transfers the equivalent meaning in the target text. This technique is used to translate an expression or a term that already common in the target language (Molina Albir, 2002). It is reflected in the sample below:

\section{Source Text:}

Hannah's Dad: You know we need to cut expenses.

Hannah's mom: We should have discussed it first.

Target Text:

Ayah Hannah: Kau tahu sendiri kita perlu memotong biaya.

Ibu Hannah: Kita harusnya membahas nya terlebih dahulu.

This speech act is an indirect verbal sign. Based on the sentence, the anger expression is possibly not be understood by the reader. However, the situation, the context, and also the tone of the voice show that the speaker is angry with her husband.

This conversation happens when Hannah's parents discuss the problem of the cost of their store. The situation is Hannah's dad cancel the meeting with the client to cut their expenses, but Hannah's mom attends the meeting without knowing it has been canceled. She has to wait for an hour that made her upset.

In the speech act, the translator used establish equivalent in all the words of these sentences, "we", "should have discussed", "it", and "first". The word "we" was translated into "kita", "should have discussed" were translated into "harusnya membahas", the word "it" representing the problem in cutting their expenses was translated into "nya" that also refers to the problem, and the word "first" was translated into "dahulu" which represent the phrase "terlebih dahulu" in Indonesia. All these words were translated into common words used in the target language, so the meaning is understood clearly by the reader or the viewer. This also supports the research by Hafisha (2018) that the use of establish equivalent techniques has a good impact on translation quality because the words were translated equivalently.

Variation

The second most dominant technique used is variation. This technique is frequently used due to the language variation in the target language, Indonesia. In the variation technique, a linguistic element or paralinguistic is changed into a linguistic element or paralinguistic in the source text (Molina and Albir, 2002).

The following is an example of a variation technique:

\section{Source Text:}

Justin: Jess, please, I was trying to protect you.

Jessica: Protect me? Seriously?

Target Text

Justin: Jess, tolong, aku berusaha melindungimu.

Jessica: Lindungi aku? Serius? 
This source text is a thinly veiled verbal sign because the speaker indicates the anger in the sentence by adding the word "seriously" to show that she could not believe what she just heard. The context of the speech act is when Justin comes to Jessica's house through her bedroom window. He tries to talk over about Jessica's rape that he could not stop Brice to rape her because Brice is his best friend and he just wants to protect her. Listening to Justin's excuse makes Jessica angry.

There are 2 translation techniques used by the translator in translating this speech act, establish equivalent and variation. In this speech act variation technique is used in translating the word "me". The word "me" has many meanings in the target text, Indonesia, such as "saya, aku, diriku" etc. To convey the correct message, the translator has to choose the appropriate one. The translator chooses to translate the word "me" into "aku" that has a good impact on the translation product. Since Jessica and Justin are in a relationship, the word " $a k u$ " shows a close relationship between them. It in line with Rahma's research (2016) shows that the variation technique is used by linking it with the speaker's social identity and the speech event.

\section{Explicitation}

The next technique often used is explicitation. According to Molina and Albir (2002), explicitation is part of amplification used to give more detailed information in the target text from implicit information in the source text. This technique is often used in translating anger speech acts because there are some terms or expressions that need to be translated in more detail to convey the whole idea in the target text. It is reflected in the sample below:

\section{Source Text:}

Hannah: Jess. You know this doesn't mean anything.

Jessica: Don't act innocent.

Hannah: But I am innocent. I had nothing to do with this. Alex did this on his own.

\section{Target Text:}

Hannah: Jess. Kau tahu sendiri ini tidak ada artinya.

Jessica: Jangan pura-pura tak bersalah kau.

Hannah: Aku memang tidak bersalah. Aku tidak ada kaitannya dengan ini. Alex yang melakukannya sendiri.

This speech indicates a direct verbal or cognitive sign: blaming. According to Yule (1996), a direct speech act is a speech act that has a relation between the structure and its function. This anger speech act is used to blame the listener by accusing the listener bluntly. The speech act happens when Jessica blames Hannah that she stoles her boyfriend, Alex.

Jessica keeps blaming Hannah even though Hannah denies it.

The translation techniques used were established equivalent and explicitation. The word innocent in the source text was translated "tak bersalah kau". The translation technique used was explicitation technique by adding the word "kau" in the target language to introduce more information about the word. In this case, the word "kau" specify the person that Jessica blames. The use of this technique is appropriate in the sentence that does not make any distortion of meaning.

\section{Pure Borrowing}

The other technique often used in translating women's anger speech act is pure borrowing. The technique is used by borrowing the word, phrase, or clause in the source text into the target text. (Molina and Albir, 2002). The sample could be seen as follow:

\section{Source Text:}

\section{Hannah: What the hell, Ryan?}

Ryan: Hannah. What's so secret you couldn't speak to me at school?

\section{Target Text:}

\section{Hannah: Apa-apaan ini, Ryan?}

Ryan: Hannah. Sepenting apa rahasiamu sampai sampai kau tak mau bicara denganku di sekolah?

This anger speech act is a direct verbal or cognitive sign: critical. This anger speech act is used to criticize someone. The anger is shown directly because Hannah conveyed the speech act harshly by yelling and throwing the magazine. In this anger speech act, Hannah criticizes Ryan's act. The context is when Ryan Published Hannah's poet that suppose to be their secret. But Ryan published it and act like nothing happened making Hannah angry at him.

Third, the translator only used compensation techniques in transferring the meaning of direct verbal or cognitive signs and indirect verbal signs. This translation technique is used to introduce the stylistic element in the target language (Molina and Albir, 2002). The technique only used a few times to transfer the meaning of anger speech acts in the target text. The compensation technique used in these speech acts has equivalent meaning in the target text so that it does not make any distortion of meaning. It is reflected in the sample below:

\section{Source Text:}

Hannah: Seriously, Marcus?

Marcus: What?

Hannah: You're such an asshole. 


\section{Target Text}

Hannah: Serius, Marcus?

Marcus: Apa?

\section{Hannah: Brengsek kau.}

This speech act is a direct verbal or cognitive sign: name-calling. The anger is shown directly in this speech act. The speaker also uses name-calling to indicate that she is angry. The context is when Marcus assault Hannah, and Hannah tries to stop him by pushing and yelling at him.

The translator used variation and compensation in translating the anger speech act. The translation technique used in translating the phrase "such an asshole" is a compensation technique where the translator changes the stylistic element in the target language without changing the message.

Another anger speech act that used compensation is indirect verbal signs.

\section{Source Text:}

Mr. Porter: I'm not trying to be blunt here, Hannah, but...you can move on.

Hannah: You mean... do nothing

\section{Target Text:}

Pak Porter: Aku tidak berusaha menjadi tumpul di sini, Hannah, tapi... Kamu bisa melanjutkan.

Hannah: Maksud Kamu...tidak melakukan apapun.

This anger speech act belongs to an indirect verbal sign because the speaker does not use the word indicating anger. However, the intonation and the expression of the speaker could be understood that the speaker displeases by the advice of the counselor. The context of the text is when Hannah tells Mr. Porter, the school counselor, about the rape that she has been through. However, Mr. Porter does not help her to punish the culprit. He suggests her to forget about the rape and move on. It makes Hannah upset and questions his advice.

The translation techniques used were compensation and establish equivalent. The phrase "you mean" was translated into "maksud kamu" by using the compensation technique. As a result, the translator could convey the meaning equivalently without any distortion of meaning.

Fourth, the translator only used paraphrase techniques in reflecting the meaning of direct verbal or cognitive signs and thinly veiled verbal signs. Paraphrase is a translation technique used to restate or reword the meaning of a text from the source text into the target text (Harmon, 2013). The use of this technique makes an equivalent translation. The technique is reflected in the samples below:

\section{Source Text:}

Jessica: We were friends. How could you betray me like that?

Hannah: Like what? What did I do?

Jessica: Is it you and Alex now?

\section{Target Text}

Jessica: Kita dulu bertemen. Teganya kau mengkhianatiku seperti itu?

Hannah: Seperti apa? Aku memeng berbuat apa?

\section{Jessica: Apa kau pacaran dengan Alex sekarang?}

The speech act is a direct verbal or cognitive sign: suspicious. The anger is shown bluntly in the speech act. Jessica is suspicious that Hannah has a romantic relationship with his boyfriend. This speech act is conveyed when Jessica blames her as the cause of her break up with Alex. She then accuses her sarcastically.

The translation technique used in translating the sentence is a paraphrase technique by saying the same concept differently. Another example of a paraphrase technique is found in indirect Tverbal signs. he sample could be seen below:

\section{Source Text:}

Clay: How are you doing?

Alex: How am I doing? How are you doing? Yeah. Target Text

Clay: Apa kabar?

Alex: Kabarku?

Kau sendiri? Ya.

This anger speech act is an indirect verbal sign. Alex does not show the anger sign in the speech act. However, the gesture and the intonation shows that he is upset by the question. The context is when Clay and Alex meet accidentally in the office. Clay asks Alex about his condition. Alex is annoyed by the question because he believes that Clay already knows about his relation with Hannah's death from the tapes. 
The translation techniques used were paraphrase and establish equivalent. The clauses "How am I doing?" and "How are you doing?" were translated using paraphrase techniques. The translator rewording the clauses into "Kabarku?" and "kau sendiri?". This paraphrase technique conveys the meaning without any distortion of meaning.

Fifth, the translator only used generalization, linguistic amplification, linguistic compression, and adaptation in conveying the meaning of direct verbal or cognitive sign and thinly veiled verbal sign. These techniques only used once in direct verbal or cognitive signs and thinly veiled verbal signs because there were only a few speech acts needed to be generalized, amplified linguistically, compressed linguistically, and adapted. The followings are the sample of each technique.

Generalization

This technique is used to translate the word, phrase, or clause into more general or more neutral. (Molina and Albir, 2002). The translator uses this technique to generalized a term or an expression to ease the reader to get the point o the speech act. It is reflected in the sample below:

\section{Source Text}

Hannah: I'm so sorry, okay?

Hannah's Mom: I just convinced the landlord to work with us to pay the back rent. I don't know what to say.

\section{Target Text}

Hannah: Aku minta maaf, oke

Ibu Hannah: Aku hanya meyakinkan pemiliknya Untuk bekerja dengan kami untuk membayar uang sewa kembali. Aku tidak tahu harus berkata apa.

This speech act is a thinly veiled verbal sign. The speaker does not convey the anger bluntly in this speech act. However, she gives a sentence indicating she is angry "I don't know what to say". This clause shows that the speaker does not believe that her daughter is careless. The context is when Hannah lost the money that will be deposited. Her mom is disappointed with her because she has tried her best to convince the landlord but she lost the money.

The translation techniques used were established equivalent, variation, and generalization. The translation technique used to translate "the landlord" is a generalization that the translator generalized the owner of the store into "pemiliknya" which means an owner. The used of the generalization technique did not distort the meaning, so it give a good impact on the translation product

Linguistic Amplification

Linguistic amplification is a technique used to specify or describe a word a phrase or clause by adding a linguistic element of the target language (Molina \& ALbir, 2002). It is reflected in the sample below:

\section{Source Text}

Headmaster: What I'm saying is that, in light of your lawsuit, I shouldn't even be talking to you.

Hannah's Mom: I see. So then why are you?

\section{Target Text:}

Kepala Sekolah: Maksudku adalah, mengingat gugatanmu...,...aku seharusnya tidak bicara denganmu. Ibu Hannah: Ah begitu. Jadi kenapa kau mau bicara denganku sekarang?

This speech act is a thinly veiled verbal sign. The speaker does not express the anger harshly. She used sarcasm questions at the end of the speech act, "why are you?" indicating anger. The context is when Hannah's mom comes to the school to ask about the death of her daughter to the headmaster. However, because Hannah's mom has reported the school related to Hannah's death, and the school is in the investigating process, the headmaster does not want to cooperate with her. It makes Hannah's mom upset and satirizes him.

Established equivalent, variation, and linguistic amplification were used to translate women's anger speech act. The translation technique used in translating the clause "why are you" is linguistic amplification. It gives more detailed information about the clause. In this speech act, the phrase "why are you" was translated into "kenapa kau mau bicara denganku sekarang". The translation contains the act and the time that is implicitly said in the source text.

Linguistic Compression

Linguistic compression was also used in translating women's anger speech acts. It is the opposite of linguistic amplification. This technique is used to synthesize the linguistic element in the target language (Molina and Albir, 2002). It is reflected in the sample below:

\section{Source Text:}

Clay: Christ, Courtney, you've got two gay dads!

Courtney: Yeah, and I have since I was in preschool, when no one had gay dads. Do you have any idea what that's like?

Target Text:

Clay: Courtney, kau saja punya dua ayah yang gay! 
Courtney: Ya, sejak aku TK...,.saat semua orang lain tidak punya ayah yang gay. Apa kau tahu bagaimena rasanya?

This speech act is a thinly veiled verbal sign, the anger in the speech act is indicated by an interrogation sentence at the end of the speech act. The phrase "Do you have any idea what that's like?" shows that she is offended by what clay said. The context is when Clay blames Courtney as someone who ruins Hannah's life and lies about his identity as a lesbian. However, Courtney is upset that no one has known her to suffer about guy dads that she has.

The translation techniques used were establish equivalent, variation, linguistic compression. The translation technique used in translating the phrase "no one" into "semua orang lain" is linguistic compression that the translator gathers linguistic elements from the source language and the target language. These techniques used in translating women's anger speech act give a good impact on the translation product because there is no distortion of meaning.

Adaptation

Adaptation technique is used to find the cultural equivalence from the source language into the target language (Molina and Albir, 2002). It is reflected in the sample below:

\section{Source Text:}

Pratters: Maybe she should try a diet.

Hannah: Seriously, Pratters? Jesus!

Pratters: I'm just saying, all right, if you're getting fat-shamed, then... you know, don't be fat. Target Text:

\section{Pratters: Mungkin dia harus diet.}

\section{Hannah: Serius, Pratters? Astaga!}

Pratters: Aku cuma bilang saja, kalau kau malu karena gemuk.. ...ya jangan sampai kau gemuk.

The anger speech act is a thinly veiled verbal sign. The speaker shows that she disbelieves what she just heard. The speaker also used the word" Jesus" to emphasize that she does not like what she just heard. The context is when Pratters bullies his fat friend in Mrs. Bradley's sharing session. It makes Hannah angry that he mocked her.

The translation techniques used were established equivalent, and adaptation in the word "Jesus". The word Jesus is hardly ever used in expressing surprise, shock, etc in the target text. As a result, the translator changed the word into a similar meaning in the target language. In line with this Rahma (2016) stated that the adaptation technique used to adjust the culture equivalent in the target text. The adaptation technique used gives a good impact on the translation product. Even though there is a change of meaning to adjust the culture, but the message delivered correctly.

\section{Conclusion}

Based on the research analysis, there are trends or behavior patterns of the translator in using translation techniques in conveying the meaning of women's anger speech acts. First, the translation techniques used by the translator were various. Then, the translator tends to use establish equivalent, variation, and explicitation in translating direct verbal or cognitive signs while establish equivalent, variation, and pure borrowing are the most frequently used in translating thinly veiled verbal sign and indirect verbal sign. Third, the compensation technique is only used in translating direct verbal signs and indirect verbal signs while paraphrasing technique is only used in direct verbal or cognitive signs and thinly veiled verbal signs. In addition, generalization, linguistic amplification, linguistic compression, and adaptation techniques are only used once in direct verbal or cognitive signs and thinly veiled verbal signs.

As a technique used to translate technical terms or expressions into common terms or expressions in the target text without any distortion meaning, established equivalent becomes the most frequently used translation technique followed by variation, explicitation, and pure borrowing. Other translation techniques such as modulation, implicitation, and transportation were used several times. However, some translation techniques were only used a few times including compensation, paraphrase, generalization, linguistic amplification, linguistic compression, and adaptation. Meanwhile, there are 5 translation techniques were not used at all in translating anger speech act in this television series 13 Reasons Why Season 1 e.g. amplification, calque, description, particularization, and substitution.

Most of the translation is translated without any distortion meaning because the translator chose particular techniques appropriately. However, there are a few translation techniques that led to translation shifts due to translator mistakes in selecting translation techniques regarding the context or situation such as discursive creation, reduction, and reduction technique. Hence, a translator needs to choose the use of a translation technique cautiously to avoid distortion of meaning and create a good translation product. 
However, this study does not reveal about the translation quality since it is affected by translation techniques. This study is also lack of a description of which technique resulting in a good quality of translation. Henceforth, it is good for further researches to look out the correlation between translation technique and translation quality.

\section{References}

[1] Abdurrahmen, S. (1999). Metode Penelitian: Suatu Pemikiran dan Penerapan. Jakarta: PT Rineka Cipta.

[2] Ardi, F. A. (2011). Anger Expression in Speeches of Male and Female Characters in The Film Entitled The Butterfly Effect. Retrieved from Tesis. Universitas Sebelas Maret: https://digilib.uns.ac.id/

[3] Catford, J. C. (1965). A Linguistic Theory of Translation. Oxford: Oxford University Press.

[4] Hafisha, O. D. (2018). The Analysis of Speech Act, Translation Technique, and Translation Quality of Edward Anger Expression in Twilight Novel by Stephanie Meyer. Retrieved from Thesis. Univesitas Sebelas Maret: http://digilib.uns.ac.id

[5] Harmon, Lucyna. (2013). Paraphrasing as a translation strategy. Retrieved from https://www.researchgate.net/publication/294087258

[6] Levinson, S. (1983). Pragmatics. London: Cambridge University Press.

[7] [Mehl, M. R., \& Pennebaker, J. W. (2003). The Sounds of Social Life: A Psychometric Analysis of Students' Daily Social Environments and Natural Conversations. Journal of Personality and Social Psychology, 857-870.

[8] Meng, L. (2019). Gender in Literary Translation: A Corpus-Based Study of the English Translations of Chenzhong De Chibang. Singapura: Springer Nature Singapure Pte Ltd.

[9] Moleong, L. J. (2010). Metodologi Penelitian Kualitatif. Bandung: Remaja Rosda Karya.

[10] Molina, L., \& Albir, A. H. (2002). Translation technique revisited: A dynamic and functionalist approach. Meta: Journal des tranducteurs/Meta: Translator's Journal, XLVII (4),, 498-512.

[11] ababan, M.R. 2008.Teori Menerjemah Bahasa Inggris. Yogyakarta: Pustaka Pelajar.

[12] Nababan, M. R., Nuraeni, A., \& Sumardiano. (2012). Pengembangan Model Penilaian Kualitas Terjemahah. Kajian Linguistik dan Sastra 24 (1), 39-57.

[13] Newmark, P. (1988). A Textbook of Translations. New York: Prentice Hall.

[14] Nida, E. A., \& Taber, C. R. (1982). The Theory and Practice of Translations. Leiden: United Bible Society.

[15] Rahma, Anita. (2016). Analisis Teknik Penerjemahan Adaptasi dan Variasi pada Subtitile Film Batmen versi Bahasa Jawa Mataram . Retrieved from Thesis. Univesitas Sebelas Maret: http://digilib.uns.ac.id

[16] Regina, A. (n.d.). 13 Reasons Why - First Seasoned. Retrieved from Subscene.com: http://isubscene.xyz/subtitles/13-reasons-why-firstseason/indonesian/1552132

[17] Santosa, R. (2017). Metode Penelitian Kualitatif Kebahasaan. Surakarta: UNS Press.

[18] Searle, J. R. (1969). Speech Act. London: Cambridge University Press.

[19] Sutopo. (2006). Metodologi Penelitian Kualitatif. Surakarta: UNS Press.

[20] Tucker-Ladd, C. E. (1998). Psychological Self-Help. Retrieved from Mental Health Net: https://www.psychologicalselfhelp.org/download/

[21] Wahana, D. (2019). Analisis Terjemahan Tuturan yang Digunakan dalam Peristiwa Tutur Marah pada Webtoon Terjemahan "Flawless" (Pendekatan Pragmatik). Retrieved from Tesis. Universitas Sebelas Maret: https://digilib.uns.ac.id/

[22] Yule, G. (1996). Pragmatics. Hawaii: Oxford University Press. 